\title{
COMMUNITY ECONOMIC ZONE: AN ALTERNATIVE TO INCREASE PUBLIC WELFARE IN RURAL AREA
}

\author{
Muria Herlina \\ FISIB-UNIB, Jalan. WR.Supratman Bengkulu \\ muriaherlina@yahoo.co.id
}

\begin{abstract}
Humans' ability in fullfiling primary needs or doing their social role have an obstacle called proverty, so community cannot perform their social functions. This condition occurs in developing countries including Indonesia. Since 2014 FlipMas Indonesia (Forum Layanan Ipteks bagi masyarakat Indonesia) and CSR/BKBL PT. Pertamina (Persero) have cooperated to create an idea to decrease proverty through Social Economic Zone or also known as Kawasan Ekonomi Masyarakat (KEM) PertaminaFlip. KEM program conducts nationally by region FlipMas in many provinces and aims to increase human development index (IPM) which is a target activity focused to economic, health and education enhancement. The method used aliterature study is supported with many practices in field work nationally to know the active target community social function in KEM membership with standard success level using IPM standard Indonesia. This year is a KEM program implementation, and the reports from each province reveal that the majority of KEM activities contibuted in increasing IPM rural community especially in revenue enhancement field. The result indicates that KEM program can increase community social welfare in rural area.
\end{abstract}

Keyword: Social Economic Zone, Social welfare, FlipMas, Rural Area

\section{Introduction}

Poverty in Indonesia is still quite high, based on BPS data in 2015 it is about 28 million, of the total 17 million occurred in the countryside. This means that approximately $60.71 \%$ of poverty occurs in rural areas; these conditions become a problem with the welfare status of rural communities. The score is impacted by the Community Development Index (HDI) in Indonesia at 68.4 and is ranked fifth in ASEAN and is still ranked 108 in the world (CBS, 2016). Outside of social problems, poverty leads to economic status of being poor. The adequacy standards became controversial and depend on the person defining it. Poverty which is defined by individuals or self-definition of poverty cannot be used as a standard for society in general. It needs a national poverty measurement standard in providing the absolute poverty line that can be used in general (Segal et al., 1998). Piven and Cloward (1993) and Swanson (2001)

showed that poverty relates to three things: (1) Lack of material, poverty in this sense is understood as the situation of the difficulties encountered in obtaining goods that become basic needs. (2) Lack of decent income and wealth, that the meaning of "decent" here is often associated with a standard or poverty (poverty line) that vary from one country to another, even from one community to another, and (3) Difficulties in meeting social needs, poverty in this sense is understood as a scarcity of social services situation and the lack of accessibility of social service agencies, such as educational institutions, health and information. To overcome these problems, the Forum science and technology for society Service (FlipMas) Indonesia in partnership with PT. Pertamina (Persero) CSR / BKBL as funders, work together on community economic zones (KEM) program or widely known as KEM PertaminaFlip. This idea aims to solve the problem of poverty that is a barrier community to achieve a decent level of welfare, with indicators of standard community development index (HDI). 


\section{Social Welfare}

Various kinds of understanding or definition that used to explain the social welfare as expressed by (Wibhawa, 2010: 23; Adi, 2013: 34) and Fahrudin, 2014: 4-5), keywords from the social welfare concept is 'human relations', Another understanding of social welfare in the very broad sense includes the kinds of human actions taken to achieve better standards of life. It is not only measured by the aspect of economic and physical, but also the aspect of social, mental and spiritual life. Furthermore, social welfare is interpreted also as a condition where people can meet their needs and be able to relate to the environment as well, aimed at (1) In order to achieve a prosperous life in the sense of achieving the essentials standard of life, such as clothing, housing, food, health, and social relations harmony with the environment, (2) to achieve a good adjustment, especially with the people in their environment, for example by exploring sources, improve and develop a satisfactory standard of living.

The term "welfare", though often used and spoken, in fact, it is difficult to define precisely. Similarly, the word "social welfare" that sometimes the word "social" is replaced with the word "people," "community" and "general", thus becoming the people's welfare (political), the welfare of society (sociological), and the general welfare (public policy). Those three aspects have the same meaning with social welfare. They cannot be separated from one another in discussing social welfare, the welfare state and social policy (Herlina and Pujileksono, 2015: 3).

The understanding of social welfare as an institution and as a discipline is different. The National Association of Social Worker provides a definition of social welfare as an institution is "A nation's system of programs, benefits, and services that helps people meet social Reviews those economic, educational, and health needs that are fundamental to the maintenance of society". From these statements, it can be seen that the social welfare as a national institution functions in the form of programs, interests and services that help people to improve their lives (Zastrow, 2004: 4). Further explained, the purpose of social welfare is to meet the needs of social, economic, health and recreation both for society and the individual. Social welfare refers to the improvement of the social functions of all age groups of rich and poor. When social elements in society such as the government or the individuals themselves unable to meet the basic needs of individuals and groups in the community, then that is the time social services will be needed (Zastrow, 2004: 5). Social welfare has many areas that must be addressed include economic needs for the poor. Further described, social welfare is a social condition given by the government as a state and social welfare has three elements, namely: level where problems in social institutions in the community can be managed, the needs of society can be met, and improving life can be extended to the community (Hasanah, 2007 :). From those several definitions, it can be interpreted that the social welfare in principle is human relations, covers a wide range of holistic actions that is condition where people can meet their needs, which includes the political, sociological and public policy when discussing social welfare.

Although the construction of social welfare was designed to meet the needs of the public in general, the main target is the those who need Social Welfare Service (PPKS), defined as those who belong to disadvantaged groups, such as the poor, children and women victims of violence, child streets, child workers, people with different abilities (disability), as well as vulnerable and other marginalized groups. Community empowerment, social rehabilitation, social assistance, social insurance, social safety network, and strengthening the capacity of marginalized groups are some examples of social welfare development program (Triono, 2011). Forum of Science and Technology for Public Service (FlipMas)

Based on notarial deed No. 11 dated March 20, 2014 under Part I of Article 1, this professional organization called Forum of Science and Technology for Public Service Indonesia, for hereinafter called "FlipMas Indonesia" . It is declared in Makasar on Saturday, July 16, 2011. FlipMas Indonesia is the head of organization of FlipMas regions throughout Indonesia (paragraph 3), domiciled and is based in the city of 
Yogyakarta, which is lead by Prof. Dr. rer.nat. Sundani Nurono Soewandhi (Chapter III, article 6).

Principles, vision, mission, purpose and nature (Chapter II, article 5 to article 7 mentioned that the vision of FlipMas Indonesia is becoming a vehicle for the the intellectual community in developing of a culture and actualizing the civilization of Indonesian people in the community. While the mission of FlipMas Indonesia is to turn on the reasoning of the nation. The aim is to increase the number and quality of performance PROdikMAS (Professional Educators Society) throughout Indonesia in conducting the service of science and technology for society. It is non-political and only carries out the activities related to independence and tranquility of society. The management of various activities in FlipMas Indonesia has the full support of FlipMas regions, can be conducted independently or FlipMAS INDONESIA in collaborated with organizations / government or private agencies, in accordance with the agreement made for the benefit of the people of Indonesia. Furthermore, in paragraph 4 explained that FlipMas regions are a subsidiary of FlipMas Indonesia established and domiciled in a particular province. In Table 1 lists the name of the membership FlipMas regions in Indonesia contained in Part III of Article 6 of the notary deed of FlipMas Indonesia.

Table 1. Members and Name FlipMAS Region in Indonesia

\begin{tabular}{|c|c|c|}
\hline No & $\begin{array}{c}\text { Name of } \\
\text { FlipMAS } \\
\text { Region }\end{array}$ & Province \\
\hline 1 & Ngayah & Bali \\
\hline 2 & Hetfen & $\begin{array}{ll}\text { East } & \text { Nusa } \\
\text { Tenggara } & \end{array}$ \\
\hline 3 & Mammiri & South Selatan \\
\hline 4 & Legowo & East Java \\
\hline 5 & Jagadhita & $\begin{array}{l}\text { Daerah Istimewa } \\
\text { Yogyakarta }\end{array}$ \\
\hline 6 & Sabilulungan & West Java \\
\hline 7 & Dianmas & Central Java \\
\hline 8 & Olahbebaya & East Kalimantan \\
\hline 9 & Martabe & North Sumatera \\
\hline 10 & Fatahillah & Jabodetabek \\
\hline 11 & Seulawah & $\begin{array}{l}\text { Naggroe Aceh } \\
\text { Darussalam }\end{array}$ \\
\hline 12 & Mapalus & North Sulawesi \\
\hline 13 & Anoa & North Sulawesi \\
\hline 14 & Nosarara & Central Sulawesi \\
\hline
\end{tabular}

\begin{tabular}{|c|c|c|}
\hline No & $\begin{array}{c}\text { Name of } \\
\text { FlipMAS } \\
\text { Region } \\
\text { Nosabatutu }\end{array}$ & Province \\
\hline 15 & Sasambo & $\begin{array}{ll}\text { West } & \text { Nusa } \\
\text { Tenggara } & \end{array}$ \\
\hline 16 & Equator & West Kalimantan \\
\hline 17 & Manise & Maluku \\
\hline 18 & Batobo & $\begin{array}{l}\text { Riau dan Riau } \\
\text { Islands }\end{array}$ \\
\hline 19 & Papua & West Papua \\
\hline 20 & Tiayo & Gorontalo \\
\hline 21 & $\begin{array}{l}\text { Rafflesia } \\
\text { Besamo }\end{array}$ & Bengkulu \\
\hline 22 & Minangkabau & West Sumatera \\
\hline 23 & Siger Inovasi & Lampung \\
\hline 24 & Sriwijaya & South Sumatera \\
\hline 25 & Gamalama & North Maluku \\
\hline
\end{tabular}

Source: FlipMas Indonesia, 2014)

\section{Social Economic Zone (KEM)}

The problems of developed social welfare today shows that there is an unmet between the right and the decent basic needs because it has not obtained the social services of the State. As a result, there are still groups who experience barriers in the implementation of the social functions so cannot have life worth and dignity. This barrier is the society that bears the social welfare problems (Ramadhianto, 2013). One of the causes of social welfare problems is poverty.

As described in the introduction, the poverty rate in Indonesia is still quite high, as a solution to improve the welfare of the people, FlipMas Indonesia since 2014 created a program in cooperated with PT.Pertamina (Persero) as raised funds through corporate social responsibility (CSR). KEM Program funding can be obtained from the PT. Pertamina (Persero) in Jakarta or from PT.Pertamina (Persero) through CSR \& SME partnership program as Sumbagut region, and other regions Sumbagsel, created by FlipMas Indonesia and adapted to the conditions KEM FlipMas region, known as KEM PertaminaFlip. Each FlipMas region administers KEM customized with the name of the location of KEM are implemented, such as KEM City Niur in Central Bengkulu implemented by FlipMas Rafflesia Besamo Bengkulu province, KEM Munmafo FlipMas Hetfen East Nusa Tenggara, KEM Partungko Naginjang samosir by FlipMas Martabe 
North Sumatara (SumutPos, 2016) and other KEM.

The requirements of KEM include (1) the marginal land (uncultivated land / unproductive more or less 5 hectares (2) There is a source of water (3) The poor family (preferably) (4) The target group of 20-50 households. KEM City Niur in Bengkulu City, in the village of Taba Penanjung Niur District of Central Bengkulu, meets these requirements and is currently implementing the second year, the activities are adapted to the soil conditions and the wishes of the target group, it needs to be implemented for public participation as one of the pillars of democracy and valuebased social development, it is important in the discourse community (Adi, 2002: 84).

Based on mutual agreement (Tim FlipMas region and 50 teams of household membership of Niur City KEM) open arable land area of 5.25 hectares. The initial condition of KEM location is a grove, after cleaning in the area mentioned planted 2500 stems of Calamansi orange (Fortunella japonica), goats, poultry, nila fish farming, fruits and vegetables. In terms of economical or the increase of earning, it opens 5 hectares of land for agriculture and livestock. From a variety of activities of KEM, the community have benefited from the program fostered by PT. Pertamina (Persero) created by Rafflesia Besamo FlipMas Bengkulu region. At first, the women of targeted KEM members did not have gardens. Now, each household owns 40 Calamansi rod within the KEM area, among those citrus trees they can plant the vegetables such as kale, eggplant, beans, chickpeas. Everything was intended as weekly earnings.

Based on the calculations of activity for approximately two years, the types of activities that have a direct impact on the welfare of the family is Calamansi syrup production, because the earnings can be measured and in its marketing, the Central Bengkulu District government made a policy that each sector of departments are required to provide a syrup or orange drink kalamanti for guests and official meetings in every office. Meanwhile, other activities such as chicken, fruits and vegetables can be sold on the kalangan market (village market) which is held every week starting on Friday until Saturday, which is just one kilometer from the KEM location. Through the studies of FlipMas Bengkulu Regional team, after being evaluated from various activities, the results showed that the active members in the KEM activities experinece the increased income from an average Rp.90.000, - up to Rp.130.000, - per week from the sale of vegetables. Not much different from the KEM Bearing Riau, at first the experience crop failure, now the results of crop is overflow (Riau Pos, 2016). Also, at KEM City Niur, at first everything was planted failed to attack pigs pest, now it shows the results of vegetables satisfy the KEM member. Their turnover is much larger. After Kalamansi syrup production started in early April 2016 until early August 2016, it has achieved a turnover of Rp.46.507.000, - the turnover leads to increased incomes, which is one of indicators of the improving people's welfare.

Another success is the rate of IPM of KEM member from 47.79 in 2014/2015 into 52.21 in the year 2015/2016. This condition, although, still lower compared to the IPM of Bengkulu Province that is equal to 68.59 (BPS: 2015) However, it already reveals improvement. The nonagricultural activity in the area of health (the pilot of healthy home and Elderly Posyandu), education (free of illiteracy, and benefits of early childhood and elementary education) other activities in the form of sideline activities to establish the collaboration among KEM members once every two weeks to provide training in traditional art of remembrance / mahaban and Rabana, Other activities to support the improvement of the welfare of the KEM citizens, holding the spiritual activities to increase the faith and devotion of Niur City rural communities generally and more specifically as a member of KEM. Furthermore, other physical structures in facilitated the establishment of early childhood education as a means of increasing the early education whose funding comes from PT.Pertamina (Persero) Sumbagsel.

The above description can give an answer to those who thinks about CSR for stating that the scope of CSR practices should workers and businesses that guarantee a well-being, both for the workers themselves and social 
stakeholders outside the company. This raises the questions about the significant influence of CSR in line with the increasing social welfare CSR practices lately. In addition, the need to see if the CSR is now able to contribute consistently in social welfare or it becomes a new form of the form of social problems settlement (Brejning, 2016: 1-2). The CSR phenomenon opens the possibility of establishing a virtuous circle in which all parties benefit. Companies can maximize the benefits while increasing the welfare of stakeholders and society. Due to the increase in social welfare, it needs for consideration of the role of the government sector in the promotion of CSR management improvement (Ganuza, 2012: 25). The condition shows that corporate social responsibility is a form of action that starts from the consideration of ethical company that aims to boost the economy, improving the quality of life for employees and their families, as well as the increased quality of life of the surrounding community and society in general (Handriyani, 2013).

\section{Conclusion}

KEM is one of the new methods as an effective alternative to the welfare of rural communities. The excellence of KEM managed by the expert of prodikmas teams. Besides being able to increase revenue, KEM activities are also helpful in forming a partnership, devotion and mutual concern in health care and education. KEM implemented in 25 provinces, all have an impact on family income and other social activities. KEM PertaminaFlip can serve as an example to increase the well-being of rural communities.

\section{References}

[1] Adi Rukminto Isbandi (2013). Intervensi kominitas \& pengembangan masyarakat sebagai upaya pemberdayaan masayarakat (Edisi Revisi 2012), PT Raja Grafindo Persada, Jakarta.

[2] Brejning J (2016). Corporate Social Responsibility and the Welfare State: the Historical and Contemporary Role of CSR in the Miced Economy Welfare. Edisi ke 2. USA: Routledge.

[3] Fahrudin Adi (2014). Pengantar Kesejahteraan Sosial, PT. Refika Aditama, Bandung

[4] Ganuza JJ (2012). Corporate Social Responsibility and Social Welfare: How to Promot Socially Responsible Business Strategies. Barcelona: CREI.

[5] Handriyani AN (2013). Pengaruh Corporate Social Responsibility Terhadap Nilai Perusahaan Dengan Profitabilitas Sebagai Variabel Moderating. Jurnal Ilmu \& Riset Akuntansi 2 (5): 2.

[6] Hasanah A. (2007). Peningkatan Kesejahteraan Sosial Anak Jalanan di Terminal Klaten. Universitas Islam Negeri Sunan Kalijaga Yogyakarta.

[7] Herlina M, Pujileksono S (2015). Pekerjaan Sosial dan Perundangundangan Sosial. Malang, UM Press.

[8] Kamila N (2010). Keberfungsian Sosial Keluarga Komunitas Pemulung. JURNAL DAKWAH, 11 (1) : 45-48.

[9] Mapisangka A (2009). Implementasi CSR terhadap Kesehateraan hidup Masyarakat. JESP 1 (1): 40.

[10] Piven FF, Cloward R (1993). Regulating the Poor: The Functions of Public Welfare. Edisi ke 2. USA: Vintage Books

[11] Ramadhianto M (2013). Upaya Peningkatan Kesejahteraan Sosial Bagi Penyandang Cacat. Universitas Brawijaya.

[12] Segal EA, Brzuzy S (1998). Social Welfare Policy, Programs, and Practice. Edisi ke 1. USA: Peacock Publishers.

[13] Suharto, Edi. (2005). Membangun Masyarakat, Memberdayakan Rakyat, Kajian Strategis Pembangunan 
Kesejahteraan Sosial dan Pekerjaan Sosial. Bandung, Refika Aditama.

[14] Triono (2011). Pembangunan Kesejahteraan Sosial dalam Pusaran Desentralisasi dan Good Governances. TAPIs 7 (13): 30-31.

[15] Zastrow C (2004). Introduction to Social Work and Social Welfare. Edisi ke 8. USA: Thomson Learning, Inc.

Other sources:

[16] BPS.2015. Indeks Pembangunan Manusia menurut Provinsi, 2010-
2015 (Metode Baru http://bps.go.id/linkTableDinamis/vie w/id/1211, diakses pada tanggal 2 Agustus 2016.

[17] Riau Pos, 2016. Dulu gagal panen, sekarang hasil melimpah, di Areal KEM PertaminaFlip Kampung Bantalan (Advertorial), Sabtu 23 Juli 2016

[18] Sumut Pos, 2016. Sejahterakan Petani Melalui KEM (KEM Partungko Naginjang Samosir Binaan Pertamina, www.pertamina.com di akses 